\title{
Rainfall Runoff in Small Watershed after Wenchuan Earthquake in Western China Based on Remote Sensing Technology - A Case Study of Jianping Gully Watershed
}

\author{
Biyun Guo ${ }^{1,2 *}$, Taiping Xie ${ }^{3 * *}$, Mantravadi Venkata Subrahmanyam ${ }^{1}$ \\ ${ }^{1}$ Marine Science and Technology College, Zhejiang Ocean University, Zhoushan, Zhejiang, 316022, P.R. China \\ ${ }^{2}$ State Key Laboratory of Plateau Ecology and Agriculture, Qinghai University, Xining, 810016, Qinghai, P.R. China \\ ${ }^{3}$ Rural Economy Institute, Tongling University, Tongling, Anhui, 244000, P.R. China
}

Received: 1 August 2020

Accepted: 2 November 2020

\begin{abstract}
On May 12, 2008, the Wenchuan earthquake in Sichuan Province, China caused surface damage, frequent landslides and debris flow, which further exacerbated the flash flood hazards. Two giant debris flows in Longxi River basin (located in Wenchuan county) occurred due to heavy rainfall after the earthquake: one was on August 13,2010, and the other on August 18,2010. Reduction and risk assessment of flash floods are the key issues in post-disaster reconstruction. Due to lack of sufficient research data, hydrological prediction models are employed as important and cost-efficient mitigation tools. Wenchuan earthquake area was taken as study site in order to illustrate the influence of geographical environmental changes on micro-mechanism of mountain floods. In this paper, hydrological observation and simulations using remote sensing data and the WMS HEC-1 model are carried out in the typical flood-hitting area (Jianping Gully basin, Dujiangyan City, Sichuan Province, China). The hydrological response of rainfall runoff is discussed. Precipitation over the study area affects the runoff and floods, however precipitation has positive relation with the peak flood discharge. The simulation shows that the peak flood and runoff volume on August 13, 2010 is close to a 10-year maximum. The flash flood was the main cause of the large debris flow on that event. However, peak runoff remains the same regardless of the intensity of rainfall, which may be due to the shape of the river basin and the initial conditions of the model setting. This paper can get better understanding of the forming mechanism, evolution process, distribution and assessment of torrential flood induced by a devastating earthquake.
\end{abstract}

Keywords: earthquake, rainfall-runoff modeling, remote sensing, WMS HEC-1, curve number

*e-mail: biyunguo@163.com

**e-mail: xtp90@163.com 


\section{Introduction}

A strong shock with the magnitude of 8.0 occurred at Wenchuan county, mountainous area of Sichuan province, southwest China at 14:28 on May 12, 2008. It lasted more than $80 \mathrm{~s}$ and killed at least 68,000 people. The major zone extended $300 \mathrm{~km}$ from southwest to northeast $[1,2]$. "5.12" Wenchuan earthquake caused a series of mountain collapse, landslide, debris flow, and other geological disasters, resulting in a great loss of people's lives and property, and the change of topography, regional hydrology and ecology (Fig. 1). Numerous loose objects in the mountain area provide materials for the debris flow. Continuous rainstorm can easily trigger debris flows. Most debris flows originally occur in the form of landslides induced by rainfall before they move into a valley. Geological disaster is high level and destroyed traffic rotes, public facilities and killed almost 2000 people [1]. In the last 3 years, over 800 debris flow events occurred destroying many residential areas. For instance, Longchi and Qingping towns in Wenchuan county destroyed by floods and giant debris flows triggered by torrential rain on Aug. 13, 2010. On Sep. 24, 2008, Beichuan and Qingchuan county had a rainstorm with a 20-year maximum [2, 3]. After the earthquake, rainstorm triggered a large number of mountain torrents and debris flow in the area [4]. Obviously, torrential flood prediction and disaster reduction are vitally important during the post-earthquake reconstruction.
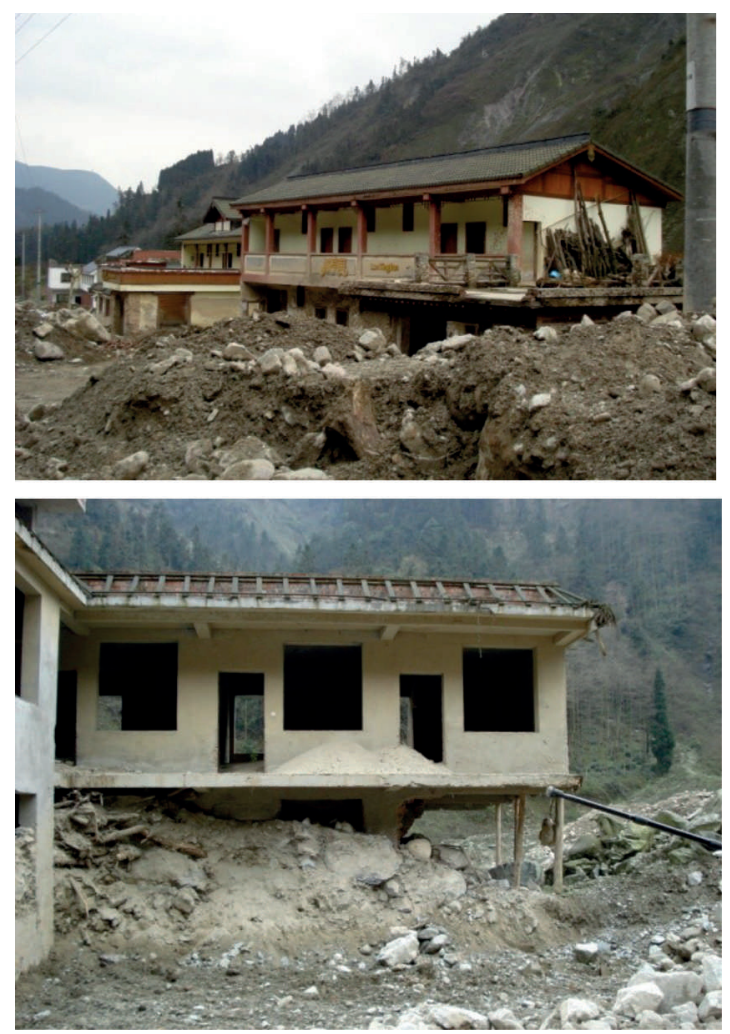

Fig. 1. Damaged houses at the mouth of the debris flow gully by the Longxi riverbank.
The greatly disrupted surface by the earthquake caused the change of the watershed hydrological process. The traditional flood evolution theory seldom considers the change of river morphology caused by the landslide. It cannot explain the serious flood after the earthquake. The simulation model for flood process using the application of satellite remote sensing, digital elevation model (DEM), geographic information systems (GIS), and hydrologic model in the recent years $[5]$.

Traditional techniques for flood estimation include the theoretical method, statistical empirical method, hydrograph techniques, and numerical models. The surface conditions affect the slop runoff (for example, soil, vegetation and terrain) [6]. Hydrography is a commonly used method to designate the response of watershed hydrological to rainfall [7]. This method tries to establish the relationship between conditions, and flood process, and thereby design an early warning.

Various runoff models are available, however it is necessary to select suitable hydrological model for mountain watershed with frequent geological disasters to ensure the effective planning and management of the basin. To analyze runoff, it is necessary to calculate infiltration parameter or flow loss rate. The infiltration capacity of surface depends on the soil attribute and land cover. Horton's and Green-Ampt equations are the most often used for evaluating infiltration of a watershed. Curve Number $(\mathrm{CN})$ is an extensively used parameter for evaluating infiltration characteristics of the basin, based on the soil characteristics and land cover. Cowan (1975) provided the soil conservation service curve number (SCS-CN) tool, which is applicable to estimate runoff in basin where vegetation, soil properties however, other physicochemical properties affecting the runoff have not been estimated experimentally. Hydrologic Modeling System (HECHMS) and Watershed Modeling System (WMS HEC1) can estimate permeability coefficient and the curve number based on precipitation and runoff. In this study, rainfall runoff was carried out using the WMS HEC-1 model. The details of model composition given in the methods section.

Due to significant flood damages in Sichuan province especially after the earthquake, Jianping Gully catchment has been chosen, as a study case based on the remote sensing (RS) data and geographic information system (GIS) technology that can simulate hydrologic processes with different modules in the WMS HEC-1 model, to reproduce the flood process on computer.

\section{Material and Methods}

\section{Study Site}

The study site, Jianping Gully basin (Fig. 2) is located in the Longmen Mountain fault zone where Wenchuan earthquake severely struck, traversing the 


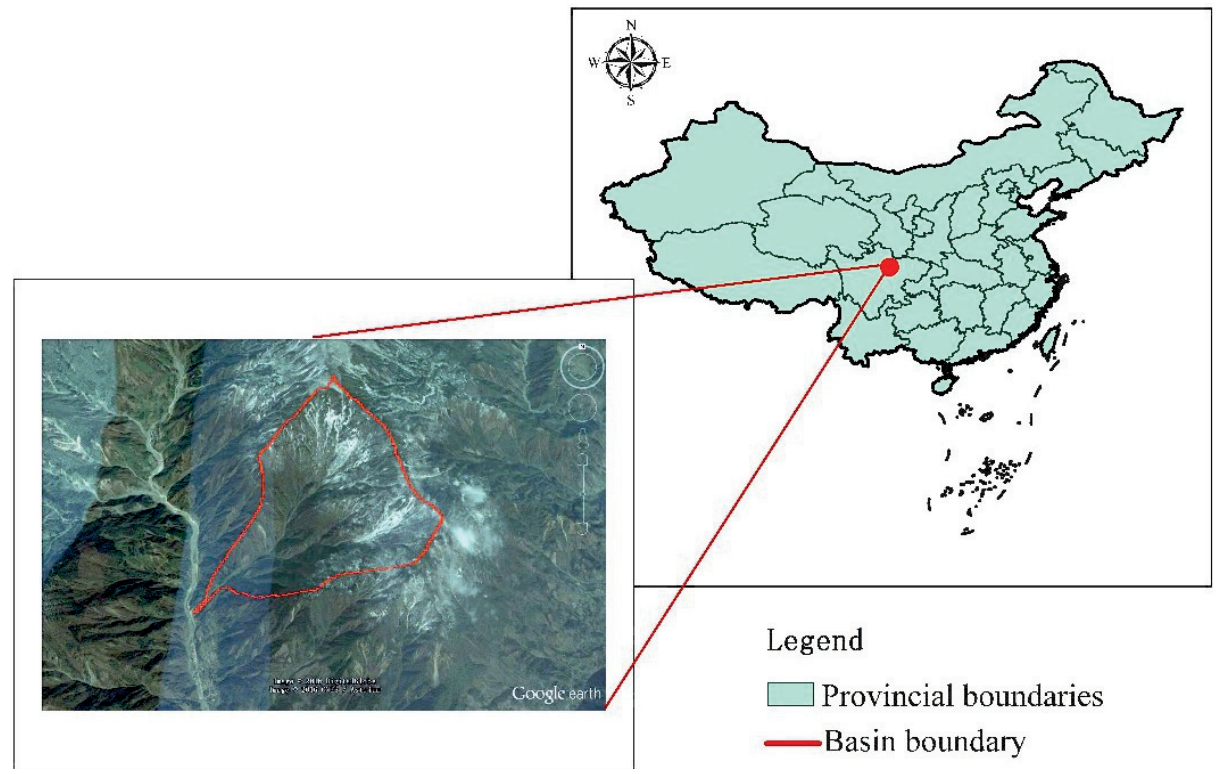

Fig. 2. Location of Jianping Gully watershed.

study site, it was the main part in the Yingxiu-Beichuan fault zone of the Wenchuan earthquake. After the great earthquake, a large number of broken rocks accumulated on the slop, which became a typical structural instability area subjected to strong weathering [8].

The $3.408 \mathrm{~km}^{2}$ Jianping Gully, is located at the Minjiang River, a tributary of the upper Yangtze River watershed. The study area is located north-west to Du Jiang Yan, with an altitude between 1060 and $2173 \mathrm{~m}$. The gully is between latitudes $31^{\circ} 05^{\prime} 18.47^{\prime \prime} \mathrm{N}$ and $31^{\circ} 06^{\prime} 40.30^{\prime \prime} \mathrm{N}$ and longitudes $103^{\circ} 33^{\prime} 47.96^{\prime \prime} \mathrm{E}$ and $103^{\circ} 35^{\prime} 26^{\prime \prime} \mathrm{E}$ (Fig. 2). For this study, the main outlet of the watershed is located at 103'33'47.96" E longitude and $31^{\circ} 05^{\prime} 18.47^{\prime \prime} \mathrm{N}$ latitude, and its altitude is $1060 \mathrm{~m}$.

Mean yearly rainfall of this basin is $1134.8 \mathrm{~mm}$, $80 \%$ of rainfall is concentrated between May and September [9]. Jianping Gully is located in the alpine valley area, which is geologically complex structure and its lithology mainly includes limestone, volcanic, shale, and sandstone [10]. In the area near Du Jiang Yan city, the annual climatological mean temperature is $15.2^{\circ} \mathrm{C}$ [9].

After Wenchuan Earthquake, geological disasters in Jianping Gully increased progressively, not only in the number of events, but also in the intensity. Heavy rainfall occurred on August 13, 2010, triggered a debris flow (the "8.13 mega debris flow") lasting for 90 minutes. Raise of riverbed about 5 to 7 meters on average due to the breakstone on the hillside slides into the valley and blocking the river channel [11]. Based on a site survey, the debris flow simultaneously occurred in two tributaries in this gully. Mountain torrents and debris flow damaged retaining wall and road, later washed into the Longxi River lower side and forming deposits (930 m long, $18 \mathrm{~m}$ wide, and $6 \mathrm{~m}$ high) [12].

\section{Data Acquisition}

The data of this study are as follows: (1) the Digital Elevation Model (DEM) is from the State Bureau of Surveying and Mapping of China (Fig. 3a); (2) the land cover interpreted from the QuickBird image using ERDAS IMAGINE 9.2 software on April 30. 2010 in the study area (Fig. 3b); (3) soil data is obtained from Data Center for Resources and Environmental Sciences, Chinese Academy of Sciences (RESDC); (4) the gridded daily rainfall data and gridded daily mean temperature for the study period collected from an automatic meteorological station in the field; (5) soil moisture measured by tensiometer at the field (Table 1). To obtain velocity and water level data, hydro dynamometer and water level gauge are used, and flow quantity along the river calculated by an integration of flow velocity over study area. The methods of remote sensing data preprocessing include geometric correction, image enhancement and radiation correction. The classification is based on spectral features used to identify the land use data in the image $[13,14]$.

In the upstream of the Jianping Gully, the terrain is very complex with steep gully and debris flow can be well developed, as well as heavy vegetation, making it difficult to access. Therefore, the instruments were installed in the middle and lower reaches of the basin for observations [15]. These monitoring sites include three precipitations, one water level and two soil moisture stations (Table 1).

\section{Methods}

Model

The Watershed Modeling System (WMS) developed and promoted by Environmental Modeling Systems, 
a)

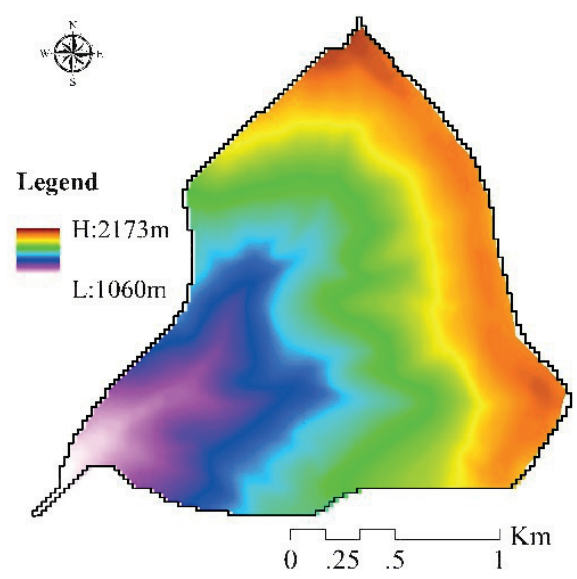

b)

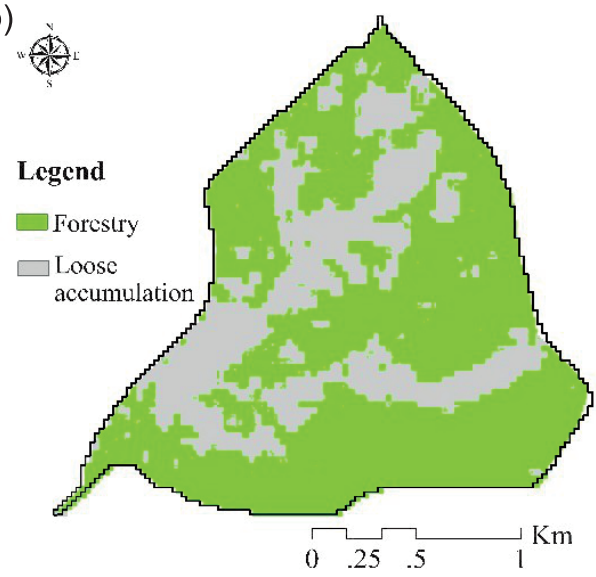

Fig. 3. a) Digital Elevation Model (DEM), b) and Land Use and Cover Change (LUCC) of Jianping Gully.

Inc. of Brigham Young University, which is an integrated graphical and visual modeling system, and suitable for each stage of watershed hydrology process [16]. The WMS is a graphically based, comprehensive hydrologic modeling environment that is designed to take advantage of watershed data developed or stored in GIS. It is not completely built in GIS with macro or programming language, but can be used to create, read and write GIS data by shape file format [17]. WMS includes many modules for hydrology processes modeling, such as automatic watershed division, terrain geometric parameter calculation, GIS cover attribute analysis (including curve numbers (CN), rainfall infiltration depth, surface roughness, etc.), and can calculate from terrain data. Based on GIS operation mode, WMS provides interfaces for various hydrological and hydraulic models. The hydrological models include HEC-1, TR-20, HEC-RAS, TR55, Modified Rational Method Model (MODRAT), Orange County rational method (Rational OC), and HSPF, GSSHA, CE-QUAL-W2, SMPDBK, and other hydrology model components [18].

HEC-1 was chosen as the hydrograph method within WMS because it can utilize soil and land use data, and can provide more precision than other models. WMS uses digital elevation model (DEM) and geomorphic information to estimate the geometric parameters. Also uses soil and surface cover to analyze the underlying surface characteristics, to simulate the hydrological process of the basin [19]. For the same reason, the SCSCN (Soil Conservation Service Curve Number) tool also uses to calculate the loss (runoff) in HEC-1 model. The curve number tool developed by the Soil Conservation Service (SCS, now NRCS) applies to describe variations of surface runoff based on land use and soil condition. Hydrography indicates the volume surface over a given time (cubic feet per second).

HEC-1 divides all land in the basin into permeable and impervious surfaces. The curve number method is obtained in a small watershed experiment, which proves the relationship between the initial infiltration $I$ and the curve number $\mathrm{CN}$. Formula is as follows $[20,21]$ :

$$
\begin{gathered}
S=\frac{1000}{C N}-10 \\
I_{a}=0.2 S
\end{gathered}
$$

Also, a relationship for excess rainfall has been established as:

$$
Q=\frac{\left(P-I_{a}\right)^{2}}{P-I_{a}+S}
$$

...where $S$ is the potential maximum retention in inch, $P$ the total precipitation in inch and $\mathrm{Q}$ the accumulated precipitation excess in inch. The range of curve number is between 0 and 100. The curve number is zero for perfectly pervious surfaces and thus $Q=0$. If curve

Table 1. The locations of the monitors in Jianping Gully

\begin{tabular}{|c|c|c|c|}
\hline Site name & Monitoring content & Longitude & Latitude \\
\hline Big stone in the entrance gutter & Rainfall, water level & $103^{\circ} 33^{\prime} 53.28^{\prime \prime}$ & $31^{\circ} 05^{\prime} 24.36^{\prime \prime}$ \\
\hline The slop in the entrance gutter & Soil moisture & $103^{\circ} 33^{\prime} 54.36^{\prime \prime}$ & $31^{\circ} 05^{\prime} 25.08^{\prime \prime}$ \\
\hline The north branch & Rainfall & $103^{\circ} 34^{\prime} 25.68^{\prime \prime}$ & $31^{\circ} 05^{\prime} 48.84^{\prime \prime}$ \\
\hline The south branch & Rainfall & $103^{\circ} 34^{\prime} 26.76^{\prime \prime}$ & $31^{\circ} 05^{\prime} 36.96^{\prime \prime}$ \\
\hline The intersection of north-south branch & Soil moisture & $103^{\circ} 34^{\prime} 26.04^{\prime \prime}$ & $31^{\circ} 05^{\prime} 36.6^{\prime}$ \\
\hline
\end{tabular}


number of impervious surface equals to 100 , then $Q=P[22]$.

In the current study, SCS unit hydrograph (SCS UH) model has been applied for estimating direct runoff. It is suggested that the UH peak (UP) and time of UH peak (TP) are related as:

$$
q_{q}=C A / T_{p}
$$

...where $\mathrm{C}=483.4$ in English system, and $\mathrm{A}$ is the drainage area square miles.

$T_{P}$ is expressed as:

$$
T_{p}=\frac{t_{r}}{2}+t_{1 a g}
$$

...where, $t_{r}$ and $t_{\text {lag }}$ are excess rainfall duration and basin lag time in hour respectively. The basin lag time is the time difference between the gravity centre of rainfall excess and the discharge hydrography at the outlet of the basin. This is an important factor to determine the unit hydrograph and peak discharge. The time parameters used in the models were time of concentration and sub basin lag time.

$$
T_{\text {lag }}=L^{0.8}\left(\left(\frac{1000}{C N}\right)-10\right)^{0.7} / 1900 \times \sqrt{y}
$$

...where, $T_{\text {lag }}$ is the lag time between the mass center of rainfall excess and the peak value of the unit hydrograph (in hour); $L$, the basin length (in $\mathrm{m}$ ); $\mathrm{Y}$, the watershed slope (in percentage); $\mathrm{CN}$, the dimensionless, curve number (between 0 and 100 ) [22], is a function of land cover, antecedent soil moisture, geomorphology and other factors affecting runoff and retention. Soil is classified into four categories: A, B, C, and D (Table2) [23].

The model uses 24-hour rainstorm. After the initial infiltration of rainfall, surface flow or runoff and a peak will occur at some point. The maximum flow affected by soil types, land cover (land use, vegetation), substream geometry (area, slope), and storm pattern. Hydrography describes the runoff process at a river point, such as at the river outlet [26].

Table 2. Description of soil classifications.

\begin{tabular}{|c|c|}
\hline Group & Description \\
\hline A & Deep and thick sand; thick loess; mortar mixing \\
\hline B & Shallow loess; sandy soil \\
\hline C & $\begin{array}{c}\text { Clay soil; shallow sandy; soil contain low organic; } \\
\text { soil contain high clay }\end{array}$ \\
\hline D & $\begin{array}{c}\text { Soil swells obviously when it is wet; heavy clay } \\
\text { soil; saline-alkali soil }\end{array}$ \\
\hline
\end{tabular}

Source: SCS (1985) [24, 25]
Table 3. Inputs of WMS HEC-1 model prepared by remote sensing and GIS techniques.

\begin{tabular}{|c|c|}
\hline Input data & Source of the data \\
\hline Basin mean rainfall & Field data \\
\hline Curve number & Assumed \\
\hline $\begin{array}{c}\text { Watershed boundary and stream } \\
\text { network of the basin }\end{array}$ & SRTM DEM \\
\hline Length and slope of the watershed & SRTM DEM \\
\hline Land use/land cover & $\begin{array}{c}\text { Quickbird image, } \\
\text { Field survey }\end{array}$ \\
\hline
\end{tabular}

\section{Preparation of Model Inputs}

The average precipitation observed at a particular raingauge station was used in WMS. The SRTM digital elevation model (DEM) uses for delineate watershed and extract drainage networks. Fig. 4 shows the stream network of the study area, which was computed by ArcMap 10.2 software. The watershed process module of WMS was used for the background map file of the study area. Another module set $\mathrm{CN}$ value as input, which selected according to the SCS National Engineering Manual and calibrated [24]. Table 3 illustrate the information of the model input.

\section{Model Calibration and Validation}

The successful application of a watershed hydrological model needs to calibrate, and is mainly depends on the measured data. The daily rainfall and runoff can be used to calibrate and test the hydrological model. The purpose of model is to match the simulated discharge, hydrograph time, and flood peak with their measured values to improve the accuracy of simulation result. In order to simulate the stream flow by using WMS HEC-1 model, surface runoff hydrographs

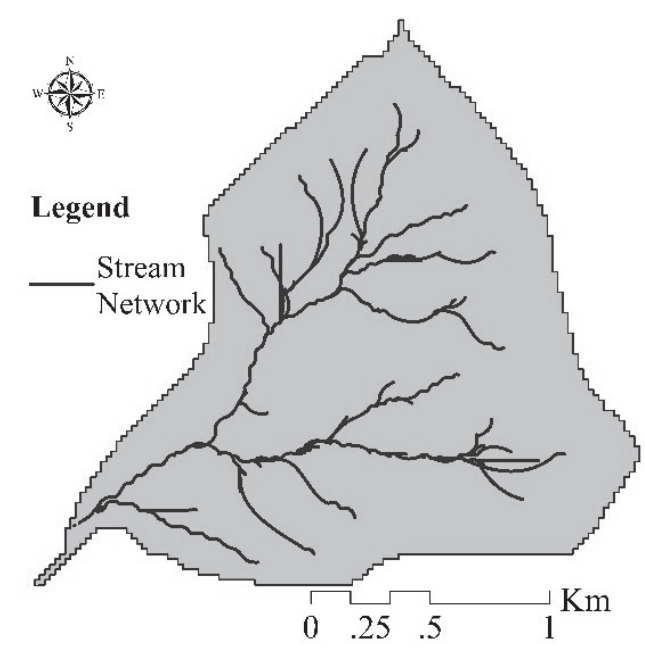

Fig. 4. Stream network of Jianping Gully watershed. 
and runoff volumes calculated by Soil Conservation Service (SCS) Runoff Curve Number method, and runoff of the single rainfall method was used for a base flow separation. The SCS lag time is a WMS HEC-1 calibration parameter. Precipitation patterns of the model are assigned to basins by the first selected the proper basin(s). In this paper, the precipitation is the basin average because the area of this watershed is small. To simulate a rainfall event, a time distribution can be input to create a rainfall distribution curve at different times in this model. The Natural Resources Conservation Service (NRCS) uses standard time distribution for different regions of the U.S, which stores in WMS. Several standard storm distributions can be loaded automatically from the model, such as 24-hour distribution, MSE3, MSE4, et al. Additionally, a series of distribution can be defined based on an actual storm or a design from a regulating agency. In this paper, the time distribution defined according to the actual storm in the research area. After the parameters calibration and corresponding simulation run, the observations and modeling results were compared.

\section{Calibration Results of WMS HEC-1}

The rainfall and runoff data in Jianping Gully use for calibrating and evaluating the accuracy of WMS HEC-1 model. The geomorphic information of the watershed extracts from digital elevation model (DEM) by using WMS HEC-1. The parameters information is shown in Table 4. The rainfall for the calibration of the WMS HEC-1 model is a 24-hour period from 18 September to 21 September 2011, and 13 October 2011, and stream flow of those five days. The rainfall obtained from rain gauges in Jianping Gully (Table 1 and Fig. 5). There are several methods for rainfall input in the WMS HEC-1 model. In this paper, we use the

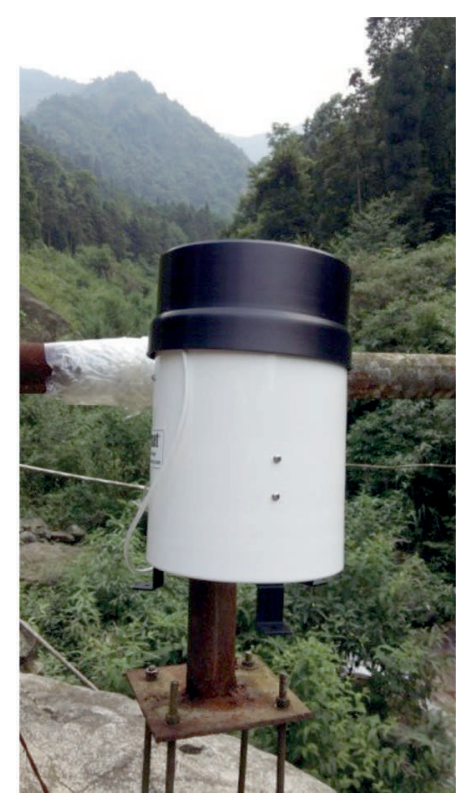

Fig. 5. The point of rain gauge placement.
Table 4. Calibration coefficients for Jianping Gully of WMS HEC-1 model.

\begin{tabular}{|c|c|}
\hline Model parameter & Data \\
\hline Basin area & $3.408 \mathrm{~km}^{2}$ \\
\hline Initial abstraction & $8.1 \mathrm{~mm}$ \\
\hline Basin CN's (curve number) & 55 \\
\hline $\begin{array}{c}\text { RTIMP (Percentage of drainage basin that is } \\
\text { impervious) }\end{array}$ & $9 \%$ \\
\hline Lag time & 0.5484 hours \\
\hline Basin slope & $0.567 \mathrm{~m} / \mathrm{m}$ \\
\hline Maximum flow (watercourse) average slope & $0.279 \mathrm{~m} / \mathrm{m}$ \\
\hline Average overland flow distance & $481.532 \mathrm{~m}$ \\
\hline Basin length & $2884.87 \mathrm{~m}$ \\
\hline $\begin{array}{c}\text { Mean basin elevation } \\
\text { Basin slope along main channel from outlet }\end{array}$ & $1714.81 \mathrm{~m}$ \\
$0.339 \mathrm{~m} / \mathrm{m}$ \\
\hline The maximum length of stream & $2191.15 \mathrm{~m}$ \\
\hline $\begin{array}{c}\text { Centroid stream slope } \\
\text { (w) }\end{array}$ & $0.257 \mathrm{~m} / \mathrm{m}$ \\
\hline
\end{tabular}

average rainfall among the three stations. Due to small basin area $\left(3.83 \mathrm{~km}^{2}\right)$, the rainfall measured by the three rain gauges is almost the same. Parameters and calibration parameters for the WMS HEC-1 model are shown in Table 4. The Holtan loss method, SCS curve number method, Uniform loss method and Green-Ampt infiltration loss method were used for runoff calculation. Those loss methods use an initial value and a uniform value to define the infiltration losses. In this paper, we use the SCS curve number method. The basin features description required for model simulation are generated from the background map, which was imported to WMS HEC-1 (shown in Fig. 6). The measured and simulated flow rates of Jianping Gully on October 13, 2011 are shown in Fig. 7. From Fig. 7, the simulated

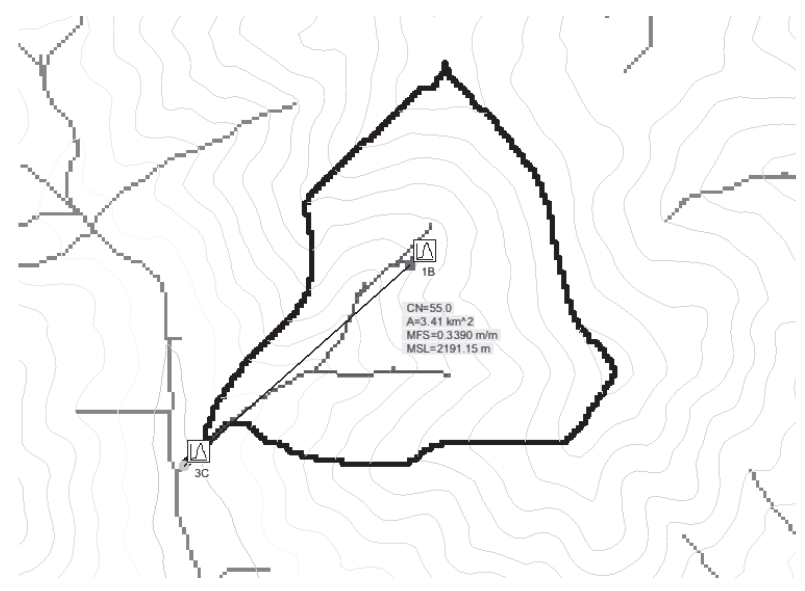

Fig. 6. WMS HEC-1model parameters and simulation process for Jianping Gully catchment. 


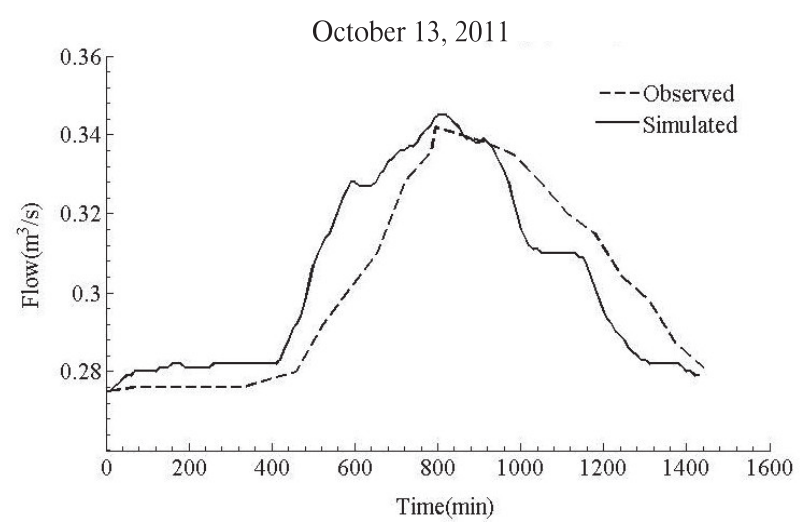

Fig. 7. Simulated Vs observed stream flow hydrograph during validation.

and measured values match well, except that the peak of the emulation value is slightly off for the timing and maximum value. The peak discharge observed is $0.342 \mathrm{~m}^{3} / \mathrm{s}$, and the model result is $0.345 \mathrm{~m}^{3} / \mathrm{s}$. The peak timing of the observation is 796 minutes, while the simulation result is 810 minutes.

The initial flow in WMS HEC-1 model is zero, but there was a background flow in the basin. The observed value is thus provided as the initial flow. This is due to runoff caused by rain in the basin prior to the study period. The initial value is $0.276 \mathrm{~m}^{3}$ per second on October 13, 2011. The simulation is consistent with the actual process, and it can be used as the basis for further analysis.

\section{Results and Discussion}

\section{The Characters of Torrential Flood Triggered by Storm on August 13, 2010}

On August 13, 2010, there was a short-term intense rainfall in Jianping Gully, the maximum rainfall was $70 \mathrm{~mm}$ per hour. Heavy rainfall induced massive debris flow occurred in Jianping Gully, the size of which was about $70000 \mathrm{~m}^{3}$. The buried area of the

\subsubsection{0}

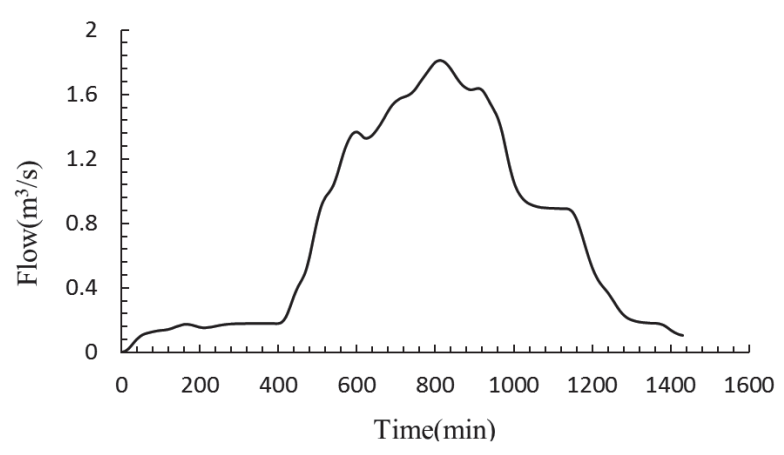

Fig. 8. Simulated stream flow hydrograph on 13 Aug. 2010. debris flow deposition at the basin outlet was about $14600 \mathrm{~m}^{2}$, with the thickness of $3 \sim 5 \mathrm{~m}$, and the length of 15-30 m. It instantly blocked Longxi River, raised water levels, threatened the communal facilities such as transmission lines, tap water factory, road and parks of downstream, as well as caused great losses of life and property on August 13, 2010. According to our field investigation, the basin is apparently in the disaster-prone stage, with topographic and source material conditions conductive to debris flow formation and secondary geological hazards by continuous rain or high-intensity rainstorms. Therefore, the rainfall of Jianping Gully on August 13, 2010 was chosen to simulate the streamflow hydrograph and flood peak discharge.

Fig. 8 shows the 24-hour flow simulation in Jianping Gully for the above-mentioned time. The simulation of flow by the WMS HEC-1 model covered the period of 0:01 AM August 13, 2010 to 0:01 AM August 14, 2010. The precipitation input into the model is the average rainfall, which was from the rain gauge in the basin (Table 1). Fig. 8 shows that the maximum flood is $1.81 \mathrm{~m}^{3}$ per second, the time of peak is 13 hours and 30 minutes (810 minutes), and the volume is $63825.6 \mathrm{~m}^{3}$.

It indicates that the " 8.13 " debris flow in Jianping Gully was induced by the heavy rainfall; the total rainfall is $209.8 \mathrm{~mm}$. According to 'Sichuan mediumsmall watershed storm flood calculation manual' published in 1984, the maximum rainfall in 10 years is $53.6 \mathrm{~mm}$ per hour and $223.6 \mathrm{~mm}$ per 24 hour [27]. Therefore, the precipitation inducing the " 8.13 " debris flow is close to once-in-10-year.

\section{The Effect of Different Storm Levels on Runoff Process over 24 Hours}

In the hydrological process of watershed, runoff affected by the characteristics of rainfall intensity and duration. Short-term intense rainfall often occurs in the flood season. Jianping Gully is located in the valley area, the equipment is easy to be destroyed by the flood, and runoff data is difficult to acquire. Therefore, there is no data recorded for the short runoff process in the flood season.

Flood return periods caused by different intensities rainstorms in small and medium-sized basins of Sichuan province can be estimated [27]. In this paper,

Table 5. The Rainfall with 24 hours for different return periods.

\begin{tabular}{|c|c|}
\hline Return period & Rainfall $(\mathrm{mm})$ \\
\hline Once in ten years & 234 \\
\hline Once in twenty years & 290 \\
\hline Once in fifty years & 364 \\
\hline Once-in-a-century & 422 \\
\hline Once-in-two-century & 478 \\
\hline
\end{tabular}




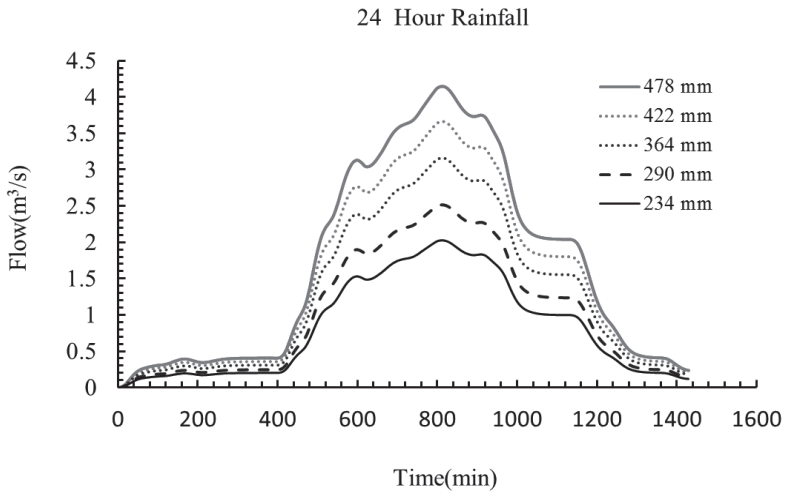

Fig. 9. The process of rainstorm runoff in different rainfall levels over 24-hour.

24- hour rainfall intensity of different flood return periods $(10,20,50,100$ and 200-year return period) in Jianping Gully basin has taken from the precipitation of WMS HEC-1 [27-29]. Table 5 indicates the rainfall corresponding to different flood return periods. The 24-hour runoff process under different rainfalls in Gully watershed simulated with the calibrated model (Fig. 9). It can be seen from Fig. 9, the different rainstorm levels mainly affect the peak discharge in the runoff process. The peak flow obviously increased when the rainstorm is increased. The peak flow of once in a decade is $2.03 \mathrm{~m} \mathrm{~m}^{3} / \mathrm{s}$, and once-in-two-century is $4.15 \mathrm{~m}^{3} / \mathrm{s}$, an increase in flow of 2.044 times. The minimum and maximum volumes are $71460.30 \mathrm{~m}^{3}$ and $145975.20 \mathrm{~m}^{3}$, respectively (Table 6). The duration of flood peak is 810 minutes for different rainfall levels.

\section{Analysis of Influence Factors of Rainfall Runoff Process in Jianping Gully Basin}

The rainstorm-runoff process in a small watershed will be affected by several factors. Topography of the basin is one of the factor. Near circular shapes are more common than elongated and narrow shapes. Jianping Gully is approximately circular $(2.49 \mathrm{~km}$ in length from north to south, $2.59 \mathrm{~km}$ from east to west, and $3 \mathrm{~km}$ long for the main channel). For a circular drainage basin, the main channel hydrograph can often be described as "flash flood" because it often gets a fairly high peak discharge. The reason is that the distances from all points to the river are roughly equal, so rainfall from different points reaches the river almost at the same time. This is why different precipitations have roughly the same time of peak discharge (the time of the peak is 810 minutes for different rainfall levels) in Jianping Gully basin. The second factor is soil and rock types. If the basin is surrounded by rocks, it will have a short lag time and a high peak discharge. The soil types in the Jianping Gully basin are sandy and humus, and a large amount of loose accumulation formed by landslides during the Wenchuan earthquake distributed in the slope and channel. Surface coverage is the third factor. The vegetation fraction affects the time of surface runoff formation and peak appearance. If there is dense vegetation cover in the basin, a large amount of rainfall can be intercepted, which will greatly increase the lag time, while the runoff volume and peak flood will decrease because of plant retaining and losing through transpiration and evaporation. Jianping Gully basin covered by dense vegetation, Wenchuan earthquake was the most disaster in history has greatly damaged the ecological environment. Through ecological restoration in recent years, the vegetation coverage has restored significantly.

\section{The Factors Triggered Debris Flow}

Jianping Gully is mainly composed of volcanic, shale, sandstone and limestone, with heavy weathering crust developed by multiple tectonic movement, generally at depth more than 10 meters. Both sides of the slope and ditches covers with a large amount of solid materials. Landslides and collapses form under the action of gravity and hydrodynamic forces, which provided solid source for debris flow, especially caused by the "5.12" Wenchuan earthquake. With the concentration of solid materials supply, a large amount of unstable accumulations in the steep valley, which was prone to the debris flow and lead to the disaster.

Another is terrain of the river and its banks. Main channel of Jianping Gully is relatively straight, with slope up being steep and down gentle, which in turn narrows the channel. The upper valley is deep cut and is particularly beneficial for the collection of solid material, precipitation and groundwater, which provide topographic conditions for the debris flow eruption.

Table 6. Partial hydrologic simulation value for 24-hour.

\begin{tabular}{|c|c|c|c|c|}
\hline Rainfall level & Rainfall $(\mathrm{mm})$ & Peak $\left(\mathrm{m}^{3} / \mathrm{s}\right)$ & Time of the peak $(\mathrm{min})$ & Volume $\left(\mathrm{m}^{3}\right)$ \\
\hline Once in ten years & 234 & 2.03 & 810 & 71460.30 \\
\hline Once in twenty years & 290 & 2.52 & 810 & 88562.40 \\
\hline Once in fifty years & 364 & 3.16 & 810 & 111165.90 \\
\hline Once-in-a-century & 422 & 3.66 & 810 & 128875.80 \\
\hline Once-in-two-century & 478 & 4.15 & 810 & 145975.20 \\
\hline
\end{tabular}


Human activities are also one of the contributing factors. Deforestation and plantation can affect the stability of mountain areas, which will aggravate mountain torrents.

\section{Conclusions}

Flash floods have caused loss of lives and properties in regions strongly affected by Wenchuan Ms8.0 earthquake on May 12, 2008. The mechanism of mountain torrent disaster is complex and difficult to prevent and control. An ideal prediction of flash flood magnitude needs to provide information about the peak flow, runoff and rainfall, which are the key parameters for the emergency prevention and construction of protecting works. The paper researches on the mountain torrent disaster following the Wenchuan earthquake, focuses on the process of the debris flow formation, the expansion of the debris flow volume, and the new method conducted to predict the flood peak discharge post-earthquake.

In this study, the WMS HEC-1 model used to simulate the torrential flooding process in Jianping Gully basin, an area worst hit by the 2008 earthquake. Remote sensing data, rainfall and GIS information are used to calibrate the model parameters. The rainfall-runoff process in the Jianping Gully basin is simulated by using the model. The field observations of precipitation and runoff required for the model. The soil collected by Harmonized World Soil Database v 1.1, and the land cover is from the classification of QuickBird remote sensing image. The drainage basin and river network information for the study site provided by DEM. The runoff process through the WMS HEC-1 model simulated, the hydrological loss calculated by SCS (Soil Conservation System) curve number method and surface runoff calculated by unit hydrograph method. The WMS HEC-1 model calibrated by rainfall stream data of October 13, 2011. Based on the observation data and the adjusted model parameters, the process of runoff triggered by heavy rainfall simulated in the small watershed after strong earthquake damages. The conclusions are as bellows:

(1) The peak flow and runoff volume of flash flood triggered by heavy rainfall in Jianping Gully basin on August 13, 2010 are close to that of a 10-year maximum. The flash flood is one of the main factors causing debris flow disaster in Jianping Gully.

(2) Based on the simulation, the time of the peak for different rainfall levels relates to the shape of the basin, and it is almost the same in a circular basin. With the increase in rainfall leads to increase in the peak discharge and runoff.

(3) Although the simulated peaks of the hydrographs are close to those observed, the streamflow hydrographs do not match well on October 13, 2011.

Overall, the results of this study have indicated that WMS HEC-1 model can reasonably simulate the rainfall runoff process in Jianping Gully watershed of Sichuan province, China. It may also be noted that the accuracy of DEM will have an important impact on watershed division in the model. This preliminary study reveals rainfall-runoff characteristics in small watershed of western China after a major earthquake, which can provide a tool for small watershed flood warning.

Experts have carried out in-depth study on the problems of debris flow initiation, evolution and accumulation, and achieved a great deal of achievements. However, the factors such as complex geometric topography, interaction between solid-liquid phases, gully rainfall recharge and infiltration have greatly increased the complexity of mathematic models. The common method is to provide the corresponding model for the process of debris flow, and to ignore or simplify some insignificant items. With terrain data used in this model obtained before earthquake, HEC-1 model was used in this study, and did not consider the influence of loose deposit after the quake, which played a significant role in the starting and evolution of debris flow in the watershed, and it is necessary to take it into account in future studies.

\section{Acknowledgements}

This study were supported by the National Natural Science Foundation of China (Grant No.51479179 and 51579230), the Science Foundation of Zhejiang Ocean University (Grant No.21105011713), State Key Laboratory of Plateau Ecology and Agriculture, Qinghai University (Grant No.2018-KF-02), and supported by China Scholarship Council (No.201508330709), Anhui Social Science Innovation and Development Research Project in 2019 (No. 2019CX016).

\section{Conflict of Interest}

The authors declare no conflict of interest.

\section{References}

1. CUI P., LIN Y., CHEN C. Destruction of vegetation due to geo-hazards and its environmental impacts in the Wenchuan earthquake areas. Ecological Engineering, 44, 7, 61, 2012. doi.org/10.1016/j.ecoleng.

2. CUI P. Foreword: special issue on Wenchuan earthquake geohazards. Environmental Earth Sciences, 65, (4), 963, 2012. DOI: $10.1007 / \mathrm{s} 12665-012-1521-6$.

3. CUI P., HU K., ZHUANG J., YANG Y., ZHANG J. Prediction of debris-flow danger area by combining hydrological and inundation simulation methods. Journal of Mountain Science, 8, 1, 1-9, 2011. DOI: 10.1007/s11629011-2040-8.

4. TANG C., ZHU J., LI W.L., LIANG J.T. Rainfall-triggered debris flows following the Wenchuan earthquake. Bulletin of Engineer Geology Environment, 68, 187, 2009. https:// doi.org/10.1007/s10064-009-0201-6. 
5. ZANON F., BORGA M., Davide Zoccatellia, Lorenzo Marchi, Eric Gaume, Laurent Bonnifait, Guy Delrieu. Hydrological analysis of a flash flood across a climatic and geologic gradient: the September 18, 2007 event in western Slovenia. Journal of Hydrology, 394 (1-2), 182, 2010. doi:10.1016/j.jhydrol.2010.08.020.

6. HALWATURA D., NAJIM M.M.M. Application of the HEC-HMS model for runoff simulation in a tropical catchment. Environmental Modelling \& Software, 46, 155, 2013. doi.org/10.1016/j.envsoft.2013.03.006.

7. RAZI M.A.M., ARIFFIN J., TAHIR T., ARISH A.M. Flood estimation studies using hydrologic modeling system (HEC-HMS) for Johor Rive, Malaysia. Journal of Applied Sciences, 10, 930, 2010.

8. DAI F.C., XU C., YAO X., XU L., TU X.B., GONG Q.M. Spatial distribution of landslides triggered by the 2008 Ms 8.0 Wenchuan earthquakes, China. Journal of Asian Earth Sciences, 40 (4), 883, 2011. DOI: 10.1016/j. jseaes.2010.04.010

9. DENG T.P. Study the development regularity and control measures in Longchi before and after the "5.12" earthquake. Master's thesis, Chengdu University of Technology, Cheng Du, China, 2011 [In Chinese with English abstract].

10. YU B., MA Y., ZHANG J., WU Y., ZHANG H., LI L., CHU S., QI X. The Group debris flow hazards after the Wenchuan earthquake in Longchi, Dujiangyan, Sichuan Province. Journal of Mountain Science, 29, (6), 738, 2011 [in Chinese with English abstract].

11. CUI P., HE S. M., YAO L. K., WANG Z. Y., CHEN X.Q. Formation mechanism and risk control in Wenchuan earthquake of mountain disaster. Beijing, China: Science Press, 2011, 133-139. ISBN: 978-7-03-030703-3 [In Chinese].

12. CHU S.M., YU B., LI L., MA Y., WU Y. F., QI X. Forming mechanism and characteristics of debris flow happened on August 13, 2010 in Jianping Gully. Soil and Water Conservation in China, 353, (8), 52, 2011 [In Chinese] DOI: $10.14123 /$ j.cnki.swcc.2011.08.001.

13. ZHANG Y.H., SUN X.M., WANG B.W. Efficient algorithm for K-Barrier coverage based on integer linear programming. China Communications, 13, (7), 16, 2016.

14. XIA Z.H., WANG X.H., SUN X.M., LIU Q.S., XIONG N.X. Steganalysis of LSB matching using differences between nonadjacent pixels. Multimedia Tools and Applications, 75, (4), 1947, 2016. doi.org/10.1007/s11042.

15. QIAN Q. Hydrologic response in a humid steep mountainous watershed in the west of China-A case study of Longxihe watershed in Sichuan. Zheiiang University, Zhejiang, doctoral thesis, China. 2014.

16. EKO K., KUSWANTORO M., AMRO M.M.E. Spatial modelling of flood inundation case study of Pesanggrahan Floodplain, Jakarta, Indonesia. Journal of Geography, Environment and Earth Science International, 5, (3), 1, 2016. Article no. JGEESI.23524 ISSN: 2454-7352. DOI: 10.9734/JGEESI/2016/23524
17. FRED L.O., JURGEN G., PAUL A., DEBARRY., LYNN E.J. GIS and distributed watershed models. II: Modules, Interfaces, and Models. Journal of Hydrologic Engineering, 6, (6), 515, 2001 DOI: 10.1061/ (ASCE)10840699(2001)6:6(515)

18. EDSEL B.D., JANEY V.C., EUGENE J.L., JESSICA R.P., JAMES P.D., MARK D.A. Watershed Modeling and its Applications: A State-of-the-Art Review. The Open Hydrology Journal, 5, (1), 26, 2011 DOI: $10.2174 / 1874378101105010026$

19. ROBERTO G., JOSE D.A., JIM N. Computation of changes in the run-off regimen of the Lake Santa Ana watershed (Zacatecas, Mexico). Lakes \& Reservoirs: Research and Management, 13, (2), 155, 2008 DOI:10.1111/ j.1440-1770.2008.00364.x

20. DILIP K. Distributed rainfall runoff modeling. International Journal of Earth Sciences and Engineering, 4, (6), 270, 2011. ISSN 0974-5904.

21. KNEBLA M.R., YANGA Z. L., HUTCHISONB K. Regional scale flood modeling using NEXRAD rainfall, GIS, and HEC-HMS/RAS: a case study for the San Antonio River Basin Summer 2002 storm event. Journal of Environmental Management, 75, (4), 325, 2005. DOI: 10.1016/j.jenvman.2004.11.024

22. Hydrologic Engineering Center. HEC-HMS flood hydrograph package User's manual. Davis: U.S. Army Corps of Engineers. 1998. http://www.wrchec.usace.army. $\mathrm{mil} /$ software/software distrib/index.htm

23. Soil Conservation Service (SCS), Hydrology, Soil Conservation Service, In SCS National Engineering Handbook: Section 4., U.S. Department of Agriculture, U.S. Gov. Print. Office, Washington, D.C., 1972.

24. Soil Conservation Service (SCS), National Engineering Handbook, U.S. Dept. of Agriculture, Washington, DC, 1985.

25. Soil Conservation Service (SCS), Urban Hydrology for Small Watersheds. Technical Release 55, United States Department of Agriculture (USDA). Washington, DC, 1986.

26. ABRAMSON MARK J. The Malibu Creek Watershed: A Framework for Monitoring Enhancement and Action. Pomona, CA: Cal Poly, Pomona- Graduate Program in Landscape Architecture. 1998.

27. Water Resources Electric Power Department of Sichuan Province, Storm flood calculation manual of middle and small basins in Sichuan Province. Beijing: Science press, 1984 [In Chinese]

28. YAN Y., Cui Y., Tian X., HU S., GUO J., WANG Z., YIN S., LIAO L. Seismic signal recognition and interpretation of the 2019 "7.23" Shuicheng landslide by seismogram stations. Landslides, 1, 2020. https://doi.org/10.1007/ s10346-020-01358-x

29. YAN Y., CUI Y., GUO J., HU S., WANG Z., YIN S. Landslide reconstruct using seismic signal characteristics and numerical simulation: A case study of the 2017 "6.24" Xinmo landslide. Engineering Geology, 270, 5, 105582, 2020. 